\title{
LA ESTATUA MARMÓREA DEL DUQUE DE LERMA EN EL CASTILLO DE DÉNIA, OBRA DE GIUSEPPE CARLONE*
}

\author{
Àngel Campos-Perales ${ }^{1}$ \\ Universitat de València
}

El 28 de agosto de 1612 Juan Vivas de Cañamás, embajador en Génova del rey Felipe III, encargó al escultor genovés Giuseppe Carlone una gran estatua de mármol blanco de Polveracio, que representaba, según el dibujo adjunto al contrato, la figura de un caballero. El retratado no era otro que el duque de Lerma, cuya efigie marmórea fue encargada para presidir desde finales de 1613 su castillo y palacio de la ciudad valenciana de Dénia. En este sentido, la obra se enmarca históricamente en el proceso de renovación del castillo que llevó a cabo Lerma desde finales del siglo XVI, reformas que incluyeron la incorporación de este exclusivo encargo artístico hasta ahora desconocido por la historiografía.

Palabras clave: duque de Lerma; Giuseppe Carlone; Juan Vivas de Cañamás; Felipe III; castillo de Dénia; Génova; estatua de mármol.

\section{THE MARBLE STATUE OF THE DUKE OF LERMA BY GIUSEPPE CARLONE IN THE CASTLE OF DENIA}

On the $28^{\text {th }}$ of August of 1612, Juan Vivas de Cañamás, the ambassador of king Philip III in Genoa, commissioned the Genoese sculptor Giuseppe Carlone to carve a large statue made of Polveracio white marble representing, according to the drawing attached to the contract, the figure of a knight. The portrait depicts none other than the Duke of Lerma, whose marble effigy was intended to preside in his castle and palace of the Valencian city of Denia and was installed there at the end of 1613. In this sense, the work is historically framed in the process of renovation of the castle that Lerma began at the end of the $16^{\text {th }}$ century and that included the incorporation of this exclusive artistic commission, heretofore unknown to historians.

Key words: Duke of Lerma; Giuseppe Carlone; Juan Vivas de Cañamás; Philip III; castle of Denia; Genoa; marble statue.

Cómo citar este artículo / Citation: Campos-Perales, Àngel (2018): "La estatua marmórea del duque de Lerma en el castillo de Dénia, obra de Giuseppe Carlone”. En: Archivo Español de Arte, vol. 91, núm. 364, Madrid, pp. 395-410. https://doi.org/10.3989/aearte.2018.24.

La figura de Francisco Gómez de Sandoval y Rojas (Tordesillas, 1553-Valladolid, 1625), V marqués de Dénia, IV conde de Lerma desde 1575 y I duque de Lerma desde 1599, sigue ofreciendo a los investigadores perfiles poco conocidos. A pesar de contar con una extensa relación

* El presente trabajo ha sido realizado en el marco de una estancia de investigación en el Museo Nacional del Prado como becario Prado-Meadows Museum del curso académico 2016-2017. Agradezco a Mercedes Gómez-Ferrer, Piero Boccardo, Roberto Santamaria, José Luis Colomer y Diane Bodart su ayuda y provechosos comentarios.

1 campean93@outlook.es / ORCID iD: http://orcid.org/0000-0001-5929-6772. 
de estudios biográficos, sobre todo centrados en sus años de acceso al poder (1599-1618) y en el ámbito geográfico que conformaron a modo de triángulo cortesano las ciudades de Madrid, Valladolid y Lerma, poco sabemos de su trayectoria personal durante los reinados de Carlos V y Felipe II y de su carrera y aspiraciones en los estados que poseyó lejos de Castilla, como fueron los de Dénia, protagonistas de estas líneas. De una forma análoga, los estudios sobre coleccionismo y mecenazgo artístico del que fuera valido de Felipe III se han visto igualmente atraídos por este marco espacio-temporal, considerado mucho más relevante para su investigación, frente a la supuesta ausencia de protagonismo, influencia y patrocinio de Lerma en épocas y lugares ajenos para la historiografía.

El propósito del presente trabajo no es solamente contribuir a paliar tal vacío de estudios en la literatura sobre Lerma, sino también dar a conocer y contextualizar históricamente una pieza única entre los bienes de nuestro protagonista y el coleccionismo nobiliario de la España del momento: una gran estatua de mármol contratada en Génova que Lerma decidió emplazar en su castillo y palacio de la ciudad valenciana de Dénia. De este modo, contrariamente a lo que han afirmado autores como Williams, quien aseguró que "Francisco Gómez sólo tenía un interés discreto por sus tierras y posesiones levantinas" 2 , trataremos de demostrar, como lo han hecho otros estudiosos, que sus estados valencianos verdaderamente le preocupaban. Quedan, en efecto, buenos recuerdos de su mandato, como fue el hecho de convertir a Dénia en escenario efímero de la Corte en 1599 y 1604, o el otorgamiento del título de ciudad a esta misma localidad en 1612. Más aún, mandó hacer una serie de obras y mejoras en el marquesado de las que ha quedado recuerdo en documentos y vestigios constructivos. De todas ellas, fueron sin duda las llevadas a cabo en su palacio y fortificación las que más recursos le supusieron. A esta gran renovación de su residencia y castillo, de manera que entonces era considerado "uno de los más vistosos edificios y más fuertes de la costa de España"”, dedicaremos las siguientes notas, proceso que incluyó la incorporación a la plataforma del mismo de la ya mencionada estatua marmórea traída desde Italia.

\section{“Obras y mejoras" del duque de Lerma en el castillo y palacio de Dénia}

El hallazgo de un documento inédito en el Archivo Ducal de Medinaceli de Toledo muestra a las claras tales labores constructivas en el marquesado de Dénia, en general, y en la fortificación de esta ciudad, en particular. Fechado el 10 de enero de 1647 en Dénia y descrito como "Relazión de lo que valían las obras y demás vienes que están en el estado de Denia hechas por el señor Duque Cardenal y otra memoria de las mejoras que hizo dicho señor en este estado", el documento fue redactado con la intención de probar y verificar las obras y mejoras, así como sus "valuas", que el duque de Lerma había materializado en sus posesiones valencianas. Tal pormenorizado informe fue mandado hacer por Mariana de Sandoval, III duquesa de Lerma, VII marquesa de Dénia e hija del nieto del duque-cardenal, su homónimo. Seguramente detrás de esta decisión se encontraba el deseo de cuantificar y justificar la herencia legal que ésta debía percibir en el contexto del grave pleito sucesorio planteado tras la muerte del nieto del duque de Lerma sin hijo varón ${ }^{5}$. Más concretamente, el problema afloró a partir de la muerte en 1624 del primogénito del duque de Lerma, Cristóbal, I duque de Uceda, un año antes que su padre. Tras la muerte de Lerma en 1625, Francisco Gómez de Sandoval, es decir, su nieto, se convirtió en el legítimo heredero y en II duque de Lerma. Su fallecimiento en 1635 sin hijos varones desencadenó, como ya hemos dicho, el litigio sucesorio del que forma parte el documento en cuestión.

\footnotetext{
2 Williams, 2008: 188.

3 Palau, 1975 [1643]: 158.

${ }^{4}$ Relazión de lo que valian las obras y demás vienes que están en el estado de Denia echas por el señor Duque Cardenal y otra memoria de las mejoras que hizo dicho señor en este estado, 10 de enero de 1647, Archivo Ducal de Medinaceli, Toledo (ADM), Denia-Lerma, legajo 18, n. 4.

5 García/Sebastián, 1983: 25.
} 
No había habido, sin embargo, ningún problema sucesorio durante los primeros cinco marqueses de Dénia, vinculándose los estados al primogénito varón ya desde el inicio de su existencia. El primero de los titulares fue Diego de Sandoval, quien obtuvo la dignidad nobiliaria de I marqués en 1485, reforzándose así la posición de la casa en el Reino de Valencia. La presencia de la estirpe en Dénia se remontaba a 1431, año en el que Alfonso V el Magnánimo otorgó a Diego Gómez la ciudad valenciana como compensación de la pérdida de sus mayorazgos en Castilla después de su intervención en las guerras civiles castellanas contra el favorito Álvaro de Luna y sus aliados 6 . El II marqués de Dénia fue Bernardo de Rojas y Sandoval, mayordomo mayor de la reina Juana desde 1519 y uno de los veinte grandes de Castilla desde 1521 por voluntad de Carlos $\mathrm{V}^{7}$, lo cual permitió a la estirpe aumentar sus posibilidades de promoción social a través de las alianzas del III y IV marqués con linajes de la misma categoría: Luis de Sandoval y Rojas, III marqués de Dénia, casó con Catalina de Zúñiga y Cárdenas, mientras que su hijo, Francisco de Sandoval y Rojas, IV marqués y padre del duque de Lerma, contrajo matrimonio con Isabel de Borja, hija de San Francisco de Borja, IV duque de Gandía ${ }^{8}$.

Pese a ello, la historia de los marqueses de Dénia durante el siglo XVI es una historia de relativa pobreza y endeudamiento. De hecho, fue la grave situación financiera heredada por Lerma tras la muerte de su padre en 1574 la que forzó al futuro valido a dirigirse a Felipe II en 1585 en busca de socorro económico ${ }^{9}$. El problema residía en las bajas rentas anuales que el linaje recibía en comparación con las más altas cantidades de otras casas nobles con el mismo estatus, de ahí posiblemente la ausencia de mecenazgo artístico por parte de Lerma antes de su llegada al poder y su claro deseo de reparar su fortuna y el honor familiar en la corte. Sin embargo, Lerma no sólo asumió a partir de 1574 una vergonzante situación de estrechez económica, pues heredó además los títulos y posesiones que había reunido su padre, entre las que estaba el marquesado de Dénia, con su castillo y palacio a la cabeza.

Como ha apuntado Bernardo J. García, "la fisionomía urbana de Denia y su importancia estratégica viene marcada por la presencia de un castillo y sus fortificaciones exteriores sobre el promontorio que dio nombre y fama a esta villa" ${ }^{10}$. En efecto, la situación privilegiada de la fortaleza sobre la colina natural que se eleva junto a la costa permitía controlar el doble puerto de la villa y resguardar un gran número de habitantes, de ahí que fuera considerado en aquellos momentos una de las "llaves del reino" de Valencia (fig. 1). Consciente de la posición estratégica que ocupaba el castillo y deseoso de agasajar al futuro rey Felipe III, Lerma comenzó ya desde al menos 1597 a renovar y alterar la antigua construcción medieval ${ }^{11}$. En efecto, como afirmara Palau ${ }^{12}$ en 1643, Chabás ${ }^{13}$ en 1876 e Ivars ${ }^{14}$ en 2015, el V marqués mejoró las fortifi-

6 García, 1998: 307. Williams, 2010: 28-29.

7 García, 1998: 307-308. Williams, 2008: 190.

8 Williams, 2008: 191.

9 Feros, 2002: 88 y ss.

10 García, 2004: 47

11 En el Archivo Ducal Medinaceli se conserva una carta de Francisco de Miranda, gobernador de Dénia, dirigida al V marqués en la que se le informa del estado de ciertas obras en el castillo, cuyas capitulaciones están ya hechas. No obstante, se le explica que éstas no puedan empezarse hasta septiembre de 1597 por falta de agua. Carta de Francisco de Miranda al marqués de Dénia, 21 de mayo de 1597, Toledo (ADM), Archivo Histórico, legajo 50, ramo 1, sin foliar. Josep Ivars opina que el grueso de las obras datan de los años en que Lerma fue virrey de Valencia (1595-1597). Ivars, 2015: 36 .

12 "Mandó [el V marqués] renovar el palacio añadiendole un quarto, y galeria, y fortificar el Castillo de manera, que oy es uno de los mas vistosos edificios, y mas fuertes de la costa de España, obra que costo 50 mil ducados". Palau, 1975 [1643]: 158-159.

13 "La plaga de estos mares eran en el siglo XVI los corsarios africanos [...]. Para prevenirse bien á la defensa mandó [el V marqués] renovar el castillo, fortificándole y haciendo varias obras en el Palacio, de modo que quedó uno de los mejores de la costa de España". Chabás, 1876: tomo II, 123.

14 Ivars, 2015: 36-37. Según paralelismos formales y estilísticos, Josep Ivars atribuye la "renovación total" del palacio a cualquiera de los muchos arquitectos que trabajaron para el marqués en la villa de Lerma, y entre estos, principalmente a Francisco de Mora. 


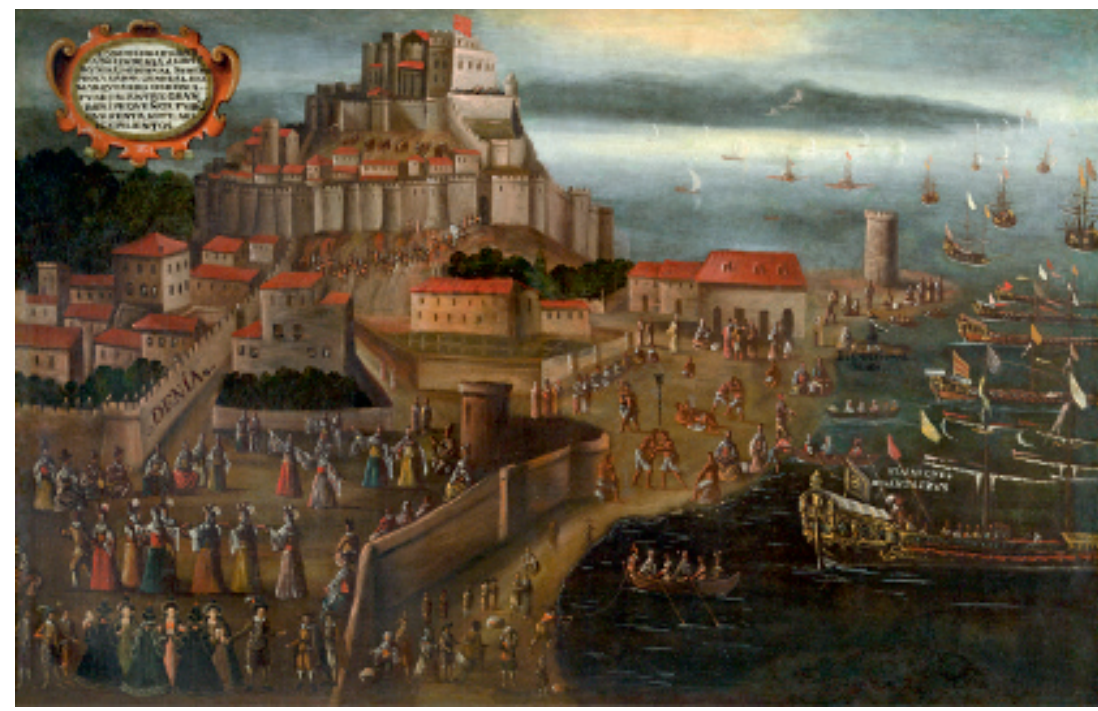

Fig. 1. Embarco de los moriscos en el Grao de Dénia, Vicent Mestre, 1613. Colección de la Fundación Bancaja, Valencia.

caciones exteriores y, lo que es más importante, llevó a cabo una serie reformas en la residencia palaciega conocida como Palau Vell, de las que han quedado evidencias materiales.

El principal problema hasta el momento era que no se conocía ninguna documentación relativa a este gran legado constructivo del V marqués. Sin embargo, gracias a la ya comentada relación de bienes y mejoras que emprendió el duque de Lerma en dicho castillo, podemos conocer no solamente el estado pormenorizado - habitación por habitación - de cada uno de los aposentos que articulaban la construcción con sus dimensiones detalladas en palmos valencianos, sino también los bienes que estaban en su interior y exterior. Así, Lerma añadió al frente oriental del viejo palacio una galería privilegiada de aposentos reales con extraordinarias vistas al mar, a fin de acondicionarlo según las necesidades y predilecciones de la familia real. En el frente norte se construyeron jardines privados para el duque y el monarca, donde también se encontraba la dehesa, una tierra acotada y destinada al desarrollo de actividades cinegéticas. El frente sur de la antigua residencia medieval quedaba, además, parcialmente oculto por una monumental escalera en forma de $\mathrm{T}$ invertida, creando una escenografía ideal para el desarrollo de fiestas y espectáculos en la plataforma del castillo (fig. 2). De este modo, mientras que Antonio Gastaldo y Cosme Traver, maestros obreros de la villa, fueron los encargados de evaluar las obras arquitectónicas y su mobiliario interior, otros personajes como Juan Martorell, pintor, Pedro Benast, platero, Jacinto del Olmo, sastre, y Onufrio Ramon, artillero, fueron requeridos para proporcionar las respectivas relaciones de pintura, plata, prendas de vestir y artillería legadas por el V marqués ${ }^{15}$. Todas estas obras y mejoras fueron cuantificadas en el testamento del duque de Lerma de 1625, donde aseguró que "en la mi ciudad de Denia, la cassa prinçipal que e hecho en el castillo" y, más tarde, "en el castillo de Denia", se había gastado "seis quenttos y quattroçienttas y diez mill maravedís" 16 .

Por otra parte, no deja de ser curioso el hecho de que puedan fecharse el grueso de tales reformas unos años antes de la primera visita de Felipe III a Dénia con motivo de las dobles bodas

15 Estamos preparando futuros estudios que analizarán más detenidamente el documento en cuestión. A parte de la relación de reformas y bienes localizables en el castillo, el escrito de 1647 también se hace eco del legado constructivo del V marqués en sus estados valencianos, como fueron las fundaciones religiosas del Monasterio de franciscanos descalzos de San Antonio (1587) y del Monasterio de agustinas recoletas de Nuestra Señora de Loreto (1604), ambos en Dénia y de patronazgo del duque; la construcción de aduanas y edificios para la almadraba en la costa de Dénia; así como las obras de diferente tipo llevadas a cabo en las villas de Xàbia y el Palmar, también propiedad del marqués.

16 García/Sebastián, 1983: 282 y 288. 
Fig. 2. Plano de Dénia, en A. de Laborde, Voyage pittoresque et historique de l'Espagne, 18061820, vol. 2, plancha CXXXI. Detalle del castillo de Dénia.

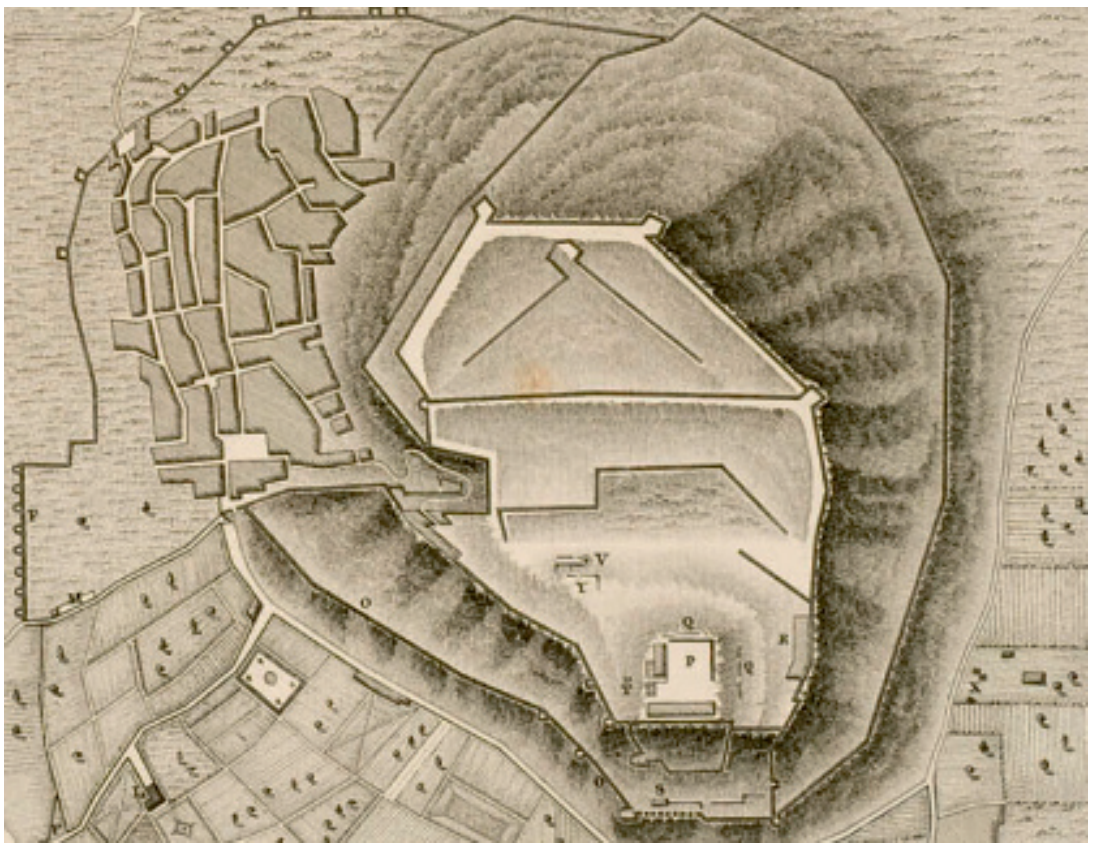

reales celebradas en Valencia, años en los que "ni el presente ni el futuro de Lerma estaban completamente claros, y más que de Dios, su destino dependía todavía del viejo monarca [Felipe II] y de sus favoritos" ${ }^{\prime 17}$. Es más, Felipe II había escogido a la ciudad de Barcelona como sede para la celebración de las dobles bodas y allí se estaban realizando los caros preparativos de arquitecturas efímeras ${ }^{18}$. Sea como fuere, sin embargo, la bodas entre Felipe III y Margarita de Austria, por un lado, y entre Isabel Clara Eugenia y el archiduque Alberto, por el otro, terminaron celebrándose en Valencia en la primavera de 1599. Las dobles bodas estuvieron acompañadas por unos fastos que se concentraron principalmente en los espacios urbanos de Valencia y Dénia ${ }^{19}$. En el caso de Dénia, la presencia de la comitiva real supuso un claro gesto de complacencia y distinción por parte del monarca hacia su nuevo favorito, que volvería nuevamente a repetirse en enero de 1604 con motivo de la celebración de Cortes en Valencia. ${ }^{20}$

En definitiva, con la transformación de su palacio de Dénia según los gustos del monarca y con el cultivo de sus aficiones, Lerma buscaba incluir otra de sus residencias personales en la agenda de Felipe III, contribuyendo así a la asimilación de la misma como un "real sitio" más ${ }^{21}$. Sin embargo, el monarca no volvería a visitar Dénia después de 1604. La presencia del marqués en sus estados valencianos fue igualmente esporádica, debido sobre todo a los quehaceres del gobierno y al engrandecimiento de su villa de Lerma.

No obstante este absentismo, el $\mathrm{V}$ marqués prosiguió dedicando su atención al aderezo de su "casa" valenciana, aunque esta vez para su mayor gloria. El proceso de embellecimiento del castillo culminó simbólicamente en 1613, cuando Lerma decidió instalar en la plataforma del mismo una de las piezas más importantes de toda su colección artística, hasta ahora desconocida

17 Feros, 2002: 106.

18 García, 2004: 34

19 Momentos de placer que fueron inmortalizados por cronistas y poetas, como Lope de Vega, quien escribió en 1599 Fiestas de Denia. Véase Vega, 2004 [1599].

${ }^{20}$ Felipe III visitó el castillo de Dénia entre el 12 y el 16 de febrero de 1599; entre el 25 de julio y el 7 de agosto de 1599; entre el 11 y el 24 de agosto de 1599; y entre el 16 y el 27 de enero de 1604. García, 2016: 395.

21 Véase García, 2016: 393-440. 
por la historiografía; esto es, una gran estatua de mármol conforme a su imagen y semejanza que había sido contratada un año antes en Génova al escultor italiano Giuseppe Carlone. En intentar esclarecer su génesis y la naturaleza de su encargo se basarán las siguientes líneas.

\section{El contrato de la escultura y su llegada a Dénia}

De toda la relación y memoria de 1647 que recogía las obras y mejoras que el duque de Lerma había realizado en el marquesado, en general, y en su castillo, en particular, destacaba en tasación una por encima de todas, descrita en el documento de la siguiente manera: "en esta plataforma [del castillo] ay una estatua de mármol del eminentissimo Cardenal Duque mi Señor, presentada por el Duque de Florencia, tassada en 15 mil libras" 22 . En efecto, la estatua marmórea a la que hacía referencia el escrito en cuestión se localizaba en la susodicha plataforma de la fortaleza del marqués, justo enfrente de la escalera principal de dos vertientes que éste había mandado erigir y que daba acceso al palacio; es decir, en la zona más elevada de la edificación, en un lugar que permitía su contemplación tanto desde el frente meridional — por donde se llegaba al palacio- como desde del oriental, desde el contiguo $\operatorname{mar}^{23}$. Así puede constatarse en el grabado Vue de Denia de A. de Laborde de inicios del siglo XIX, publicado en su monumental Voyage pittoresque et historique de l'Espagne (1806-1820) (fig. 3) y en el dibujo homónimo que sirvió para ilustrar dicha vista, de mayor fidelidad formal por lo que atañe a la realidad histórica de la escultura (fig. 4). El mismo Laborde, sin embargo, no consiguió identificar al retratado, ya que en su Plan de Denia posterior describía la escultura como "statue en marbre plus grande que nature de l'un des ducs de Medina Cœli" 24 . Resulta extraño que Laborde se limitase a reseñar que se trataba de una estatua de un "duque de Medinaceli", pues como después veremos, una extensa inscripción alrededor de su pedestal registraba ya desde 1659 que se estaba ante la efigie del duque de Lerma.

Sea como fuere, trataremos seguidamente de arrojar luz sobre los orígenes de un encargo que terminó involucrando, como vamos a comprobar, a diferentes actores. En concreto, la estatua en mármol del duque de Lerma fue contratada en Fassolo (Génova) el 28 de agosto de 1612 por Juan Vivas de Cañamás, embajador de Felipe III en Génova, quien actuaba como agente y mediador entre Lerma - su futuro propietario - el escultor genovés Giuseppe Carlone - su artífice - y probablemente el gran duque de Toscana - su presumible costeador- ${ }^{25}$. El contrato en cuestión fue dado a conocer por primera vez por Luigi Alfonso en 1977 en un fundamental trabajo sobre la actividad artística de los Carlone en la Génova del siglo XVII ${ }^{26}$. Sin embargo, el investigador italiano describió la pieza solamente como "statua di cavaliere"27, reparando además en las diferentes cláusulas del encargo que a continuación iremos desgranando.

${ }^{22}$ Relazión de lo que valian las obras y demás vienes que están en el estado de Denia echas por el señor Duque Cardenal y otra memoria de las mejoras que hizo dicho señor en este estado, 10 de enero de 1647, Toledo (ADM), Denia-Lerma, legajo 18, n. 4, fol. 26r.

${ }^{23}$ En la visita de 1766 que hizo Baltasar Venero al marquesado de Dénia afirmó que la estatua "se descubre de la maior parte de la ciudad, campo y Marina, que alcanza la vista el palacio o alcázar en que remata el castillo". Venero, 2005 [1765-1766]: 121

${ }^{24}$ Laborde, 1806-1820: vol. 2, 96. Véase la letra T de la figura . $^{\circ} 2$.

25 Como hemos visto en el documento de 1647, la estatua se creía regalada por el "Duque de Florencia", posiblemente en referencia a Cosme II de Médici, gran duque de Toscana en el año que fue contratada la obra. Conscientes de su dependencia política a la monarquía hispánica, los grandes duques de Toscana trataron de conseguir favores a través de selectos regalos a personajes importantes de la corte española, como el duque de Lerma, uno de los hombres que más se aprovecharon de estas estrategias. Goldberg, 1996a: 105-114; 1996b: 529-540. No obstante, a la espera de nuevas aportaciones documentales, esta información debe ser estimada como una mera hipótesis.

26 Alfonso, 1977. La signatura del contrato es la siguiente: Archivio di Stato di Genova (ASG), Notai antichi, notario: Domenico Tinello, signatura: 3169, 28 agosto 1612, doc. 259.

27 Alfonso, 1977: 87. 
Fig. 3. Vista de Dénia, en A. de Laborde, Voyage pittoresque et historique de l'Espagne, 18061820, vol. 2, plancha CXXX.

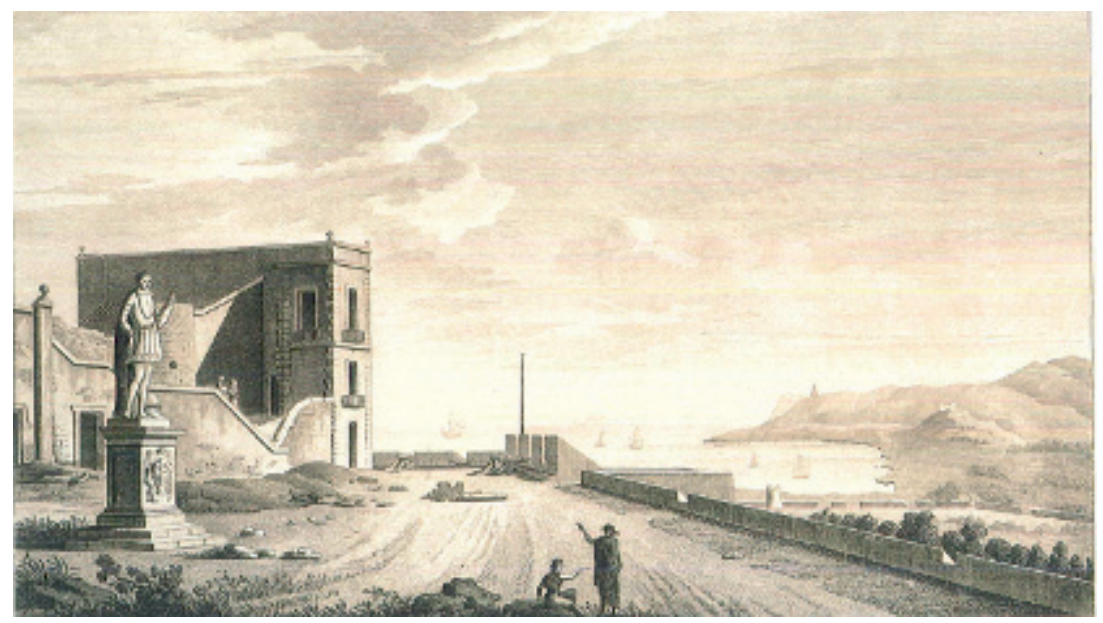

Fig. 4. Vista de Dénia, dibujo original para el grabado homónimo del Voyage pittoresque et historique de l'Espagne, c. 1800. Bibliothèque de 1'Institut National d'Histoire de l'Art, collections Jacques Doucet, Inv. 20918.

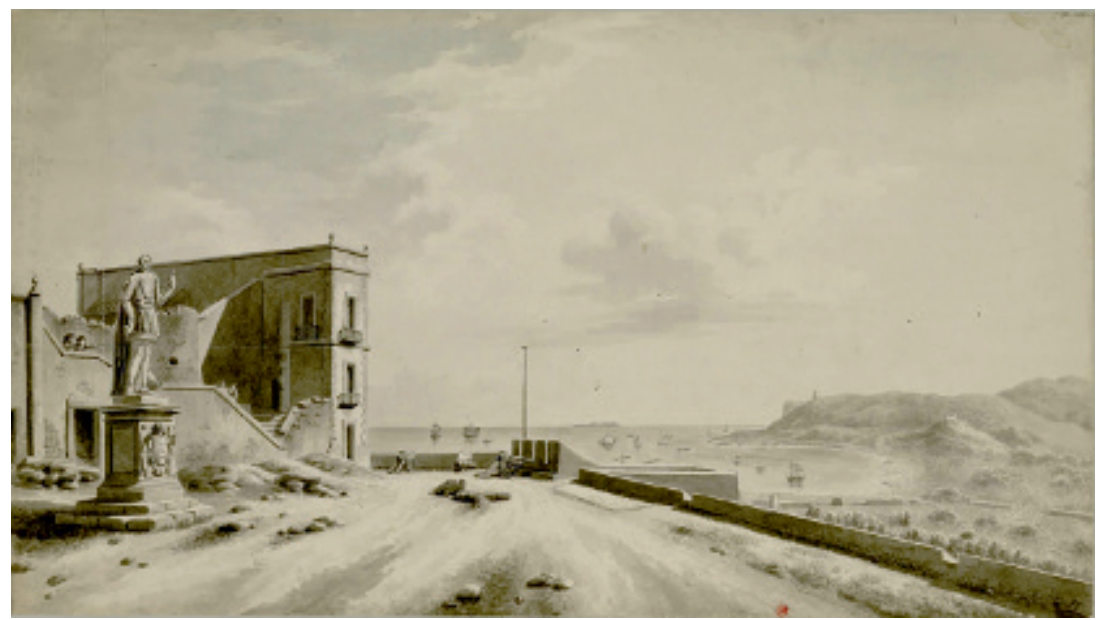

Dos años más tarde, Rosa López Torrijos volvió a considerar el mencionado encargo, publicando por primera vez el extraordinario dibujo que acompaña al contrato y que nos da una perfecta imagen de cómo era la escultura de Carlone. En su pionero, y todavía de referencia, estudio sobre el palacio genovés que erigió a principios del siglo XVII el embajador Vivas en Benifairó de les Valls (Valencia) ${ }^{28}$, Torrijos detallaba que se trataba de "la figura de un caballero", con una serie de atributos que podían vincularse "a las esferas en las que estuvo presente don Juan Vivas durante su vida al servicio de los monarcas españoles"29. En trabajos posteriores, tanto López Torrijos como otros investigadores han continuado valorando la obra como una estatua destinada al palacio valenciano de Vivas de Cañamás ${ }^{30}$. No obstante, el caballero del que hablaban Alfonso y López Torrijos no era otro que el duque de Lerma, cuya efigie marmórea estuvo destinada a presidir su palacio de Dénia.

Como ya hemos dicho, el 28 de agosto de 1612 Giuseppe Carlone, "scultor lapidum", se comprometía a fabricar y construir "sponte et omni meliori modo" una estatua de mármol blanco

\footnotetext{
28 López, 1979.

29 López, 1979: 67.

${ }^{30}$ López, 1987: 381. Galassi, 1987: 80. Franchini, 2004: 208. Montolío/Fumanal, 2015: 154-176.
} 


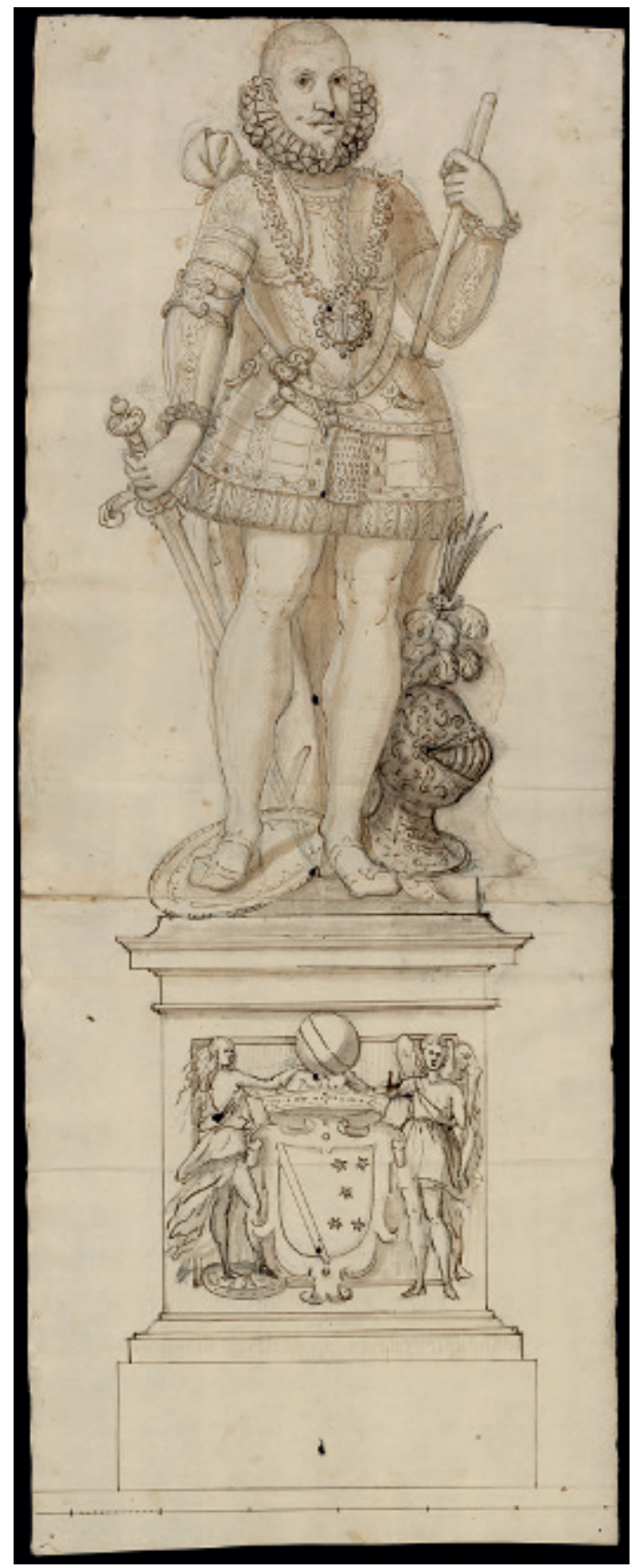

Fig. 5. Estatua marmórea del duque de Lerma, dibujo de Battista Carlone, 1612. Archivio di Stato di Genova. de Polveracio para el "Illustrissimo oratore don Joanne Vivas". Ésta se debía erigir sobre un pedestal de 6 palmos de altura y 5 de ancho, con dos figuras que debían sostener en sus manos un globo del mismo mármol y con el escudo de armas del protagonista, enmarcado dentro de un recuadro según un modelo adjunto que había sido enviado a Génova al escultor Giuseppe Carlone. Por otra parte, en la adenda del contrato se hacía referencia a un dibujo "prospectico" de la escultura marmórea, obra de Battista ("Bapta") Carlone, enviado desde Génova presumiblemente a España y al duque de Lerma para su visto bueno definitivo (fig. 5) ${ }^{31}$. La estatua había de tener 10 palmos de altura, es decir, unos 2 metros y 20 centímetros, con los que se alcanzarían 3 metros y medio de altura total. Asimismo, la obra tenía que estar terminada dentro de un plazo de ocho meses por el precio de 1000 libras en moneda de Génova, que ascendería en 200 más si el trabajo quedaba a gusto de Giacomo Vivaldo "nunc apellatus Cattaneus Pinellus". Por último, como también comentan López Torrijos y Alfonso, el contrato notarial fue dado en la villa de Fassolo en casa de Filippo Adorno, actuando el mismo Battista Carlone como garante entre el artista y el comitente ${ }^{32}$. La estatua tuvo que ser terminada dentro del plazo previsto, ya que gracias a un nuevo documento inédito sabemos que ésta embarcó en Génova, rumbo al puerto de Dénia, el 9 de agosto de 1613. Así lo contaba Juan de Ossa, secretario de la embajada española en Génova, al conde de Castro, miembro "del Consejo de su magestad y su embaxador en Roma":

Esta tarde he despachado una barca para Dénia con una estatua grande de mármol blanco de la figura del señor duque de Lerma con su pedestal, el escudo de sus armas y otras piedras para su adorno, que se an acabado con toda perfeción y han pareçido aquí en estremo de bien. El embaxador mi señor haze al señor duque esta memoria de fiel amigo y servidor y su Excelencia ha holgado grandemente dello, y se pondrá en la plaça de Dénia. Dios lo lleve con bien ${ }^{33}$.

31 El dibujo genovés mide $784 \times 284 \mathrm{~mm}$. y carece de filigrana alguna.

32 ASG, Notai antichi, notario: Domenico Tinello, signatura: 3169, 28 agosto 1612, doc. 259.

33 Carta de Juan de Ossa al conde de Castro, 9 de agosto de 1613, Archivo Ducal de Alba, Madrid (ADA), caja 24, exp. 2, sin foliar. La carta iba dirigida a Francisco de Castro, hermano de Pedro Fernández de Castro, futuro VIII conde de Lemos y embajador del rey en Roma. Cabe recordar que su hermano Pedro, VII conde de Lemos, contrajo ma- 
Ya en el puerto de Dénia, la escultura tuvo que ser descargada y transportada hasta lo alto de la ciudad por medio de carros con mulas o bueyes ${ }^{34}$. A partir de entonces y, por lo menos, hasta 1805 , último año en el que hemos encontrado evidencias documentales de su existencia, la estatua podía contemplarse en la plataforma del castillo de Dénia. Según puede verificarse en el dibujo y grabado de Laborde de inicios del siglo XIX, la estatua se encontraba durante estos años en un buen estado de conservación, manteniendo todos los atributos que la acompañaban en origen y su inconfundible postura en contrapposto. Tales atributos fueron reseñados de forma meticulosa en la aseveración del historiador dianense Roque Chabás de finales del siglo XIX, posiblemente la más valiosa descripción de la estatua que se conserva para poder reafirmar que realmente se trataba de la obra contratada por Vivas de Cañamás en 1612. Dice así:

Fué don Ambrosio nuestro octavo marqués, y para perpetuar la memoria de su abuelo, el privado de Felipe III, mandó se le erigiera una estátua de mármol, de unos diez palmos valencianos de altura. Representaba á don Francisco de Sandoval, vestido á la antigua española, con formas muy robustas, llevando un manto sobre sus espaldas, un morrion á sus pies, el collar con la cruz de Santiago pendiente del cuello, en la mano derecha una espada con la punta hácia tierra algo inclinada al manto: tenia la otra mano levantada con un baston de mando como de unos dos palmos, sostenido por mitad. [...] Serviale de pedestal una columna cuadrada de doce palmos de alto, la cual tenía en la base dos gradas, cuya altura unida á la de la columna y estátua daban una elevacion de veinticuatro palmos. En la columna ó pedestal cuadrado[...] estaban grabadas las armas de los Sandovales y Rojas, en su frente ${ }^{35}$.

Ciertos aspectos merecen ser destacados en cuanto al prolijo comentario del historiador de Dénia. Efectivamente, como puede verse en el minucioso y perfectamente terminado dibujo que acompaña al contrato notarial genovés, el duque de Lerma fue representado a la moda con calzas y armadura, portando los atributos de guerrero (escudo, espada y morrión), el bastón de mando militar y la venera de caballero de Santiago. Del cinto colgaba además una llave - la gran llave dorada - en referencia a su cargo de sumiller de corps, que le permitía abrir y cerrar todas las puertas del aposento real y tener a su cargo el cuidado de la real cámara. El atuendo del privado se completaba con un manto sobre sus espaldas, que puede intuirse en el dibujo gracias al nudo que se vislumbra sobre su hombro derecho y que se distingue claramente en el dibujo y grabado de Laborde. Es decir, Lerma fue representado como un caballero en evidentes tonos regios, fórmula que ya había sido explorada en sus anteriores retratos pintados, como el que realizó Juan Pantoja de la Cruz en 1602 (Fundación Casa Ducal de Medinaceli) o el retrato ecuestre que pintó Rubens en 1603 (Museo Nacional del Prado). Asimismo, como acertadamente comentó Chabás, en el frente del pedestal se esculpió el escudo de armas de los Sandovales y Rojas, con la característica banda de sable sobre campo de oro de los primeros y las cinco estrellas de ocho puntas de azur puestas en sotuer sobre campo de oro de los segundos. Como también se especificaba en el contrato, dos figuras tenían que estar representadas en el pedestal sosteniendo la bola del mundo. Concretamente, se tratan de personajes femeninos que pueden ser identificados como representaciones alegóricas de la Fortuna y la Fama, gracias a la presencia de sus atributos iconográficos tradicionales: la rueda de la fortuna de la primera y las alas de águila y trompeta de la segunda ${ }^{36}$.

Sin embargo, hay dos elementos en la écfrasis de Chabás que no concuerdan con el contrato genovés y que creemos pueden estar relacionados. El historiador aseguró que la estatua era de 10 palmos de altura - como se especifica en el encargo de Juan Vivas - , mientras que el pedestal era de 12 palmos y las dos gradas inferiores de 1 palmo cada una, con lo que se alcanzaban

\footnotetext{
trimonio con su prima hermana Catalina de la Cerda, la segunda hija del duque de Lerma. Agradezco la sincera generosidad de la Dra. Mercedes Simal López, quien me advirtió de la existencia de este documento.

${ }^{34}$ Para el transporte de esculturas, ya fueran de bronce o mármol, en la España de los siglos XVI y XVII, véase Di Dio/Coppel, 2013: 25-27.

35 Chabás, 1876: tomo II, 152-153.

36 Así fueron identificadas también por López Torrijos. López, 1979: 67.
} 
los 24 palmos en conjunto (más de 5 metros de altura). Creemos que la razón que puede explicar tal desfase entre alturas puede ser, por una parte, una adición posterior de las dos gradas inferiores - que no están en el dibujo original y que pueden distinguirse en el dibujo y grabado de Laborde - y, por otra, un posible aumento también a posteriori de la altura del pedestal. El personaje encargado de llevar a cabo tal elevación en la altura total de la escultura pudo ser el citado Ambrosio, VIII marqués de Dénia, quien también "mandó" que se grabase en 1659 la siguiente inscripción en los tres lados restantes del pedestal, empezando por la izquierda:

\section{Izquierda:}

Effigies del eminentis. ${ }^{\circ}$ y Exmo. Señor Don Francisco Sandoval, Cardenal de la Santa Iglesia Romana, Marqués de Denia, Duque de Lerma, Conde de Ampudia, Sumiller de Corps y Caballerizo mayor del Rey nues..$^{\circ}$ Señor Don Phelipe $3 .^{\circ}$, de sus Consejos de Estado y Guerra, Capitan General de la Caballería de España, Comendador mayor de la órden de Santiago.

\section{Detrás:}

Mandóla colocar ${ }^{37}$ el Exmo. Señor Don Ambrosio de Sandoval y Aragon, su tercer nieto, Marqués de Denia, Duque de Lerma, conde de Santa Gadea y de Buendía y de Ampudia, Marqués de Villamizar, Adelantado mayor de Castilla, hijo primogénito y socesor de los...

\section{Derecha:}

Exmos. Señores don Luis Raymundo de Aragon, Folch de Cardona, olim Fernandez de Córdoba, y de Doña Mariana de Sandoval, Padilla, Duques de Segorbe y de Cardona, Marqueses de Comares y de Pallars, Condes de Ampurias y de Pradas, Vizcondes de Villamur. Mayo 18 año $1659^{38}$.

Por lo que atañe a los aspectos estilísticos y formales de la escultura, López Torrijos ya señaló en su día que las formas del dibujo genovés adolecen de un cierto amaneramiento característico de la escultura de finales del siglo XVI, sin las particularidades de "realismo o movimiento que apuntaba ya la nueva escultura italiana en estos primeros años del siglo XVII"39. Seguramente Roque Chabás se refería a esta falta de naturalidad en la composición de la obra cuando expresó que la estatua era, efectivamente, de "formas muy robustas" 40 . Pese a ello, y aunque son evidentes tales formalismos, el rostro del excelente dibujo de Génova está sustancialmente basado en la vera effigies de Francisco Gómez de Sandoval y Rojas, lo cual se pone de manifiesto cuando comparamos tales facciones (fig. 6) con las que seguramente le sirvieron de modelo al dibujante; esto es, las del ya mencionado retrato de Juan Pantoja de la Cruz de 1602 (fig. 7) o las del cuadro de Rubens un año posterior (fig. 8). De hecho, como argumentó Sarah Schroth, Rubens vio el retrato de Pantoja y lo utilizó como prototipo a seguir en la composición de su rostro pintado de $1603^{41}$. A su vez, con la intención de mantener la imagen "oficial" del retratado, el artífice del dibujo genovés tuvo que copiar en lo esencial el rostro ejecutado por alguno de estos dos pintores. De este modo, el dibujo del contrato de Génova también presenta la faz del retratado en un perfil de tres cuartos con el contorno exterior delineado por un trazo ininterrumpido, y sigue en lo fundamental el semblante de Lerma en 1602: labios carnosos, línea del pelo marcada, ligero estrabismo, arqueado de la ceja derecha y bigote y perilla idénticos. Sin

37 Pensamos que puede hacerse referencia a la recolocación de la estatua sobre las dos gradas inferiores; o bien, que pueda aludir a colocar la susodicha inscripción, pues la estatua ya estaba en la plataforma del castillo en 1647.

${ }_{38}$ Chabás, 1876: tomo II, 153-154. Ciertamente, como también matiza Chabás, quienes mandaron grabar tal inscripción fueron los duques de Segorbe, es decir, Mariana de Sandoval y Luis Ramón de Aragón, sus padres, pues Ambrosio de Sandoval (1650-1659), IV duque de Lerma, era todavía un niño en aquellas fechas. Aunque fallecida en 1651, la voluntad de Mariana de Sandoval tuvo que influir en la decisión de colocar tal inscripción. Chabás, 1876: tomo II, 154-155.

39 López, 1979: 67.

40 Chabás, 1876: tomo II, 152.

${ }^{41}$ Schroth, 2001a: 42-43. 


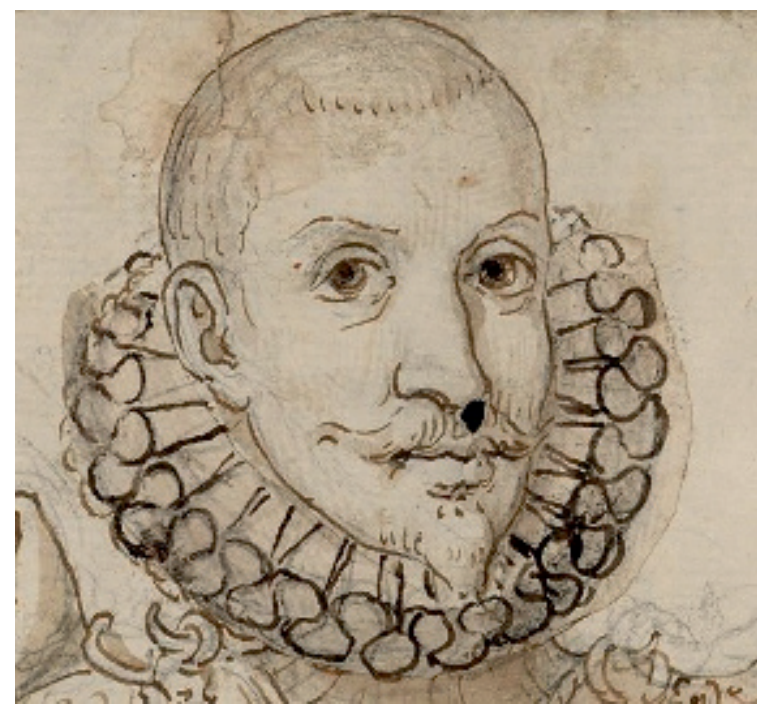

Fig. 6. Estatua marmórea del duque de Lerma. Detalle.

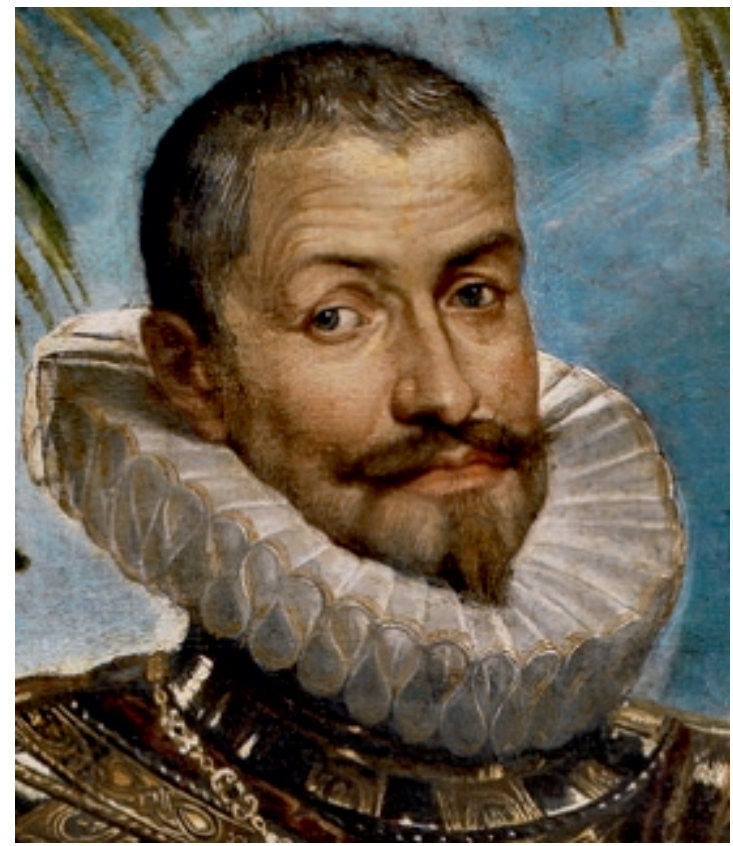

Fig. 8. Retrato ecuestre del duque de Lerma, Pedro Pablo Rubens, 1603. Museo Nacional del Prado, Madrid. Detalle.

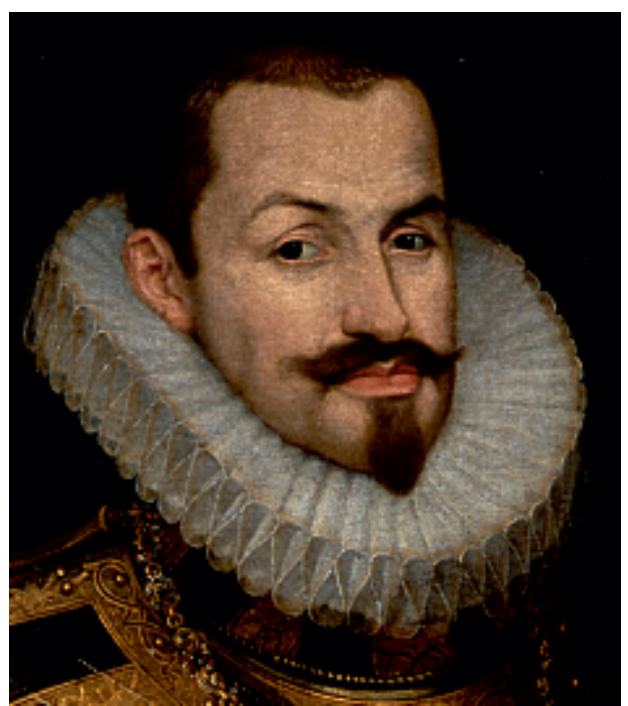

Fig. 7. Retrato del duque de Lerma, Juan Pantoja de la Cruz, 1602. Fundación Casa Ducal de Medinaceli. Detalle.

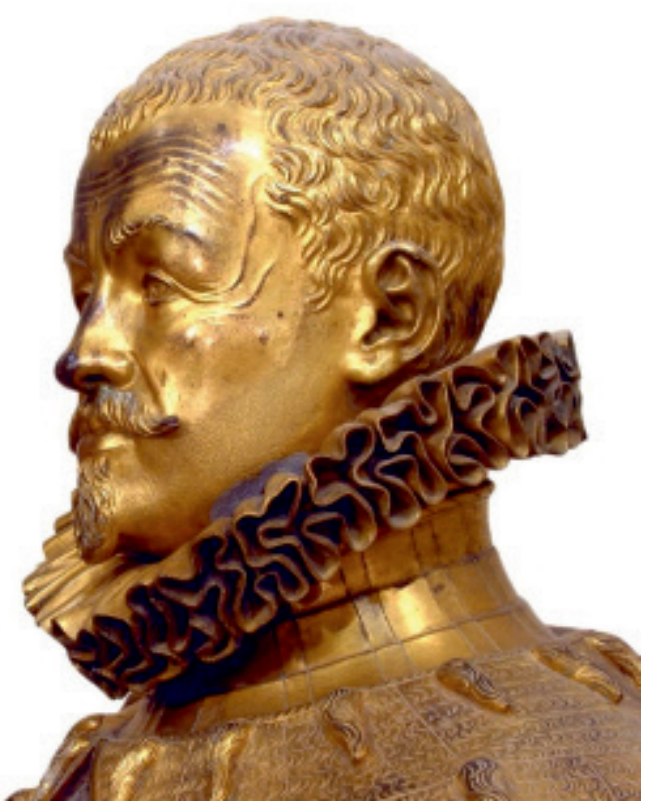

Fig. 9. Estatua orante del duque de Lerma, Pompeo Leoni y colaboradores, 1601-1608. Iglesia de San Pablo, Valladolid. Detalle.

embargo, desconocemos la forma en la cual pudo cristalizar este deseo de individualizar al retratado en manos del escultor Giuseppe Carlone, aunque nos inclinamos por pensar que no tuvo que ser tal, sobre todo si tenemos en cuenta la opinión de Chabás y el hecho de que su artífice tuviera que basarse en un modelo concebido sólo con lo esencial del rostro real de Lerma. Por ende, 
su resultado final tuvo que diferir notablemente del aspecto que presenta la estatua más popular de Lerma (fig. 9), conservada en la iglesia de San Pablo de Valladolid y realizada con una factura exquisita por Pompeo Leoni y otros colaboradores después de la llegada del italiano a esta ciudad castellana en $1601^{42}$.

Sea como fuere, la estatua para Dénia fue elaborada por Giuseppe Carlone, miembro de una conocida familia de artistas cuya presencia activa en Génova abarcaba un arco temporal de cuatro siglos, del XV al XVIII ${ }^{43}$. De la vida de Giuseppe (doc. 1599-1624), hermano de Taddeo Carlone e hijo de Giovanni Carlone, también escultores, sabemos realmente poco ${ }^{44}$, aunque lo suficiente como para advertir que no era la primera vez que había sido comisionado por Juan Vivas y que ya había colaborado en la realización de otras obras para el Reino de Valencia. En efecto, el mencionado embajador Vivas participó como intermediario en el contrato de 1609 del sepulcro de Don Juan Alfonso Pimentel, VIII conde de Benavente, virrey de Valencia de 1598 a 1602 y de Nápoles de 1603 a 1610, para el convento de Santo Domingo de Valencia, obra de Giuseppe Carlone y Oberto Casella que probablemente debió conocer el duque de Lerma. No obstante, no quedan restos materiales del sepulcro, que había sido pensado como una grandiosa sepultura de una sola persona con diferentes obras, según se desprende del encargo transcrito por Luigi Alfonso en 1977 y que originalmente iba acompañado de cuatro trazas hoy también perdidas ${ }^{45}$. Además, otras obras de Giuseppe Carlone para Juan Vivas fueron las ejecutadas para su palacio valenciano de Benifairó de les Valls, entre las que estaban tres fuentes de mármol esculpidas junto con Oberto Casella (1608), obras de decoración de los jardines (1609), una nueva fuente de mármol (1609), y una última estatua de mármol blanco de Carrara (1615) ${ }^{46}$. Asimismo, el 21 de enero de 1610 Giuseppe Carlone, su hermano Taddeo y Antonio Casella fueron contratados una vez más por Juan Vivas ${ }^{47}$, que actuaba en nombre de dos agentes de la ciudad de Valencia, para la construcción de cuatro estatuas de mármol destinadas al Puente del Real de la ciudad del Turia: una de San Vicente Mártir, una de San Vicente Ferrer, una del Beato Luis Beltrán y una de San Luis arzobispo de Tolosa.

De este modo, de la constante petición por parte de los comitentes referenciados de obtener obras genovesas en mármol de la mejor calidad y ejecución al embajador Juan Vivas, emergen dos hechos concluyentes: el extraordinario rol de intermediario que ejerció Vivas de Cañamás entre clientes españoles y artistas genoveses durante los primeros años del siglo XVII y la consiguiente posibilidad de conseguir en territorio español algunas de las mejores obras de escultura italiana del momento. Obras, al fin y al cabo, especialmente gratas para una clientela española "dada a magnificar su prestigio y su riqueza en el ámbito de una situación de predominio europeo" 48 . Conocedor de esta nada desdeñable presencia de obras genovesas en tierras valencianas y de las oportunidades que ofrecía el cargo de Vivas, el duque de Lerma se hizo representar siguiendo unos cánones sólo reservados para los grandes encargos de escultura áulica. De esta forma, la comisión de su estatua en mármol al escultor genovés no solamente puede considerarse un unicum entre el coleccionismo nobiliario de escultura del momento ${ }^{49}$, sino también una

42 Di Dio/Coppel, 2013: 144-145.

43 Alfonso, 1977: 43.

44 Galassi, 1987: 80.

45 Alfonso, 1977: 90-91. El contrato fue también transcrito en López, 1980: 83-85. Tres años antes, Vivas había comunicado a Gio. Maria Augustallo la orden de Gastón de Moncada, conde Osuna, de esculpir un sepulcro de mármol para la capilla Moncada de la iglesia de Nuestra Señora del Remedio en Valencia. Franchini, 2004: 208. Sobre la decisión de ambos personajes de contratar artistas genoveses para la construcción de sus sepulcros, sin duda debió ejercer un gran influjo el de los marqueses de Zenete de la Capilla de los Reyes del convento de Santo Domingo en Valencia, contratado a Giovanni Orsolini y Giovanni Carlone en 1564. López, 1978: 323-336.

46 López, 1979: 59-69. En este mismo trabajo López Torrijos documenta más contactos de Vivas con artistas genoveses a partir de noticias que habían sido publicadas por Alfonso dos años antes. Alfonso, 1977: 85-87.

47 Alfonso, 1977: 85. Franchini, 2004: 208.

48 Franchini, 2004: 208.

49 No hemos encontrado ningún caso similar entre el coleccionismo nobiliario de la España de los siglos XVI y XVII. Un buen ensayo acerca de las colecciones escultóricas de la aristocracia española durante este tiempo puede 
creación parangonable en exclusividad y representatividad a las conocidas esculturas marmóreas de cuerpo entero de los monarcas españoles, como el Carlos V de Leone Leoni (Museo del Prado), la Emperatriz Isabel de Pompeo Leoni (Museo del Prado) o el Felipe II de Pompeo Leoni (Patrimonio Nacional, Palacio Real de Aranjuez). De hecho, la estatua del duque de Lerma pudo incluso verse en territorio español tres años antes que el célebre retrato ecuestre en bronce de Felipe III, regalo del gran duque de Toscana que, no obstante, había sido comisionado a Giambologna en $1606^{50}$.

Por último, en cuanto a la desaparición o posible destrucción de la escultura, es probable que se produjese en los años posteriores a 1805. Nuevamente es Chabás quien nos informa de la suerte que pudo correr la obra durante tales años, pues según este historiador, en el contexto de la incorporación de Dénia a la corona en 1804, la estatua fue arrancada de su pedestal el 19 de agosto de 1805, y "la sepultaron cerca del lugar donde estaba, como también las inscripciones". Años más tarde, en el marco de la guerra de la Independencia española, "los franceses parece que la sacaron de su sitio, y luego se dice que estátua y piedras las reclamó el duque [de Medinaceli] "51. Como afirma Chabás, el duque de Medinaceli demandó en repetidas ocasiones y durante décadas una indemnización por la incorporación a la corona, según real orden del 8 de enero de 1804, de Dénia, su término, puerto y bienes, entre los que estaba, claro está, la escultura del duque de Lerma. Así se pone de manifiesto en los autos de un pleito larguísimo entre el duque de Medinaceli y los fiscales del Supremo Tribunal de Justicia conservado en el Archivo Medinaceli de Toledo. El litigio, resuelto de forma desfavorable para los intereses del duque, nada nos dice del destino final de la estatua, aunque remarca el interés que sentía la estirpe Medinaceli por recuperar una obra única que había sido "regalada por el duque de Florencia" 52 . Por ende, la meticulosa descripción de 1876 de Roque Chabás, hecha en tiempos de pretérito, tuvo que estar fundamentada en una anterior fuente documental que desconocemos y que desafortunadamente este autor no nombró.

\section{Epílogo. Aproximación a su significado}

Realmente, por lo que atañe a los retratos esculpidos, lo más popular y habitual entre las colecciones escultóricas de la aristocracia de la época eran los bustos, cuya prevalencia se explicaba sobre todo por el deseo de emular las series de bustos de las colecciones reales ${ }^{53}$. Los bustos antiguos de emperadores, ya fueran copias u originales, se coleccionaban ávidamente y, algunas veces, se instalaban junto con bustos de personajes contemporáneos, ubicados normalmente en las hornacinas de los muros del jardín. Tal fue el caso del mismo duque de Lerma, quien poseyó en su palacio madrileño del Paseo del Prado "24 estatuas de Emperadores de mármol blanco con sus pedestales", conjunto que había comprado en 1602 a Don Álvarez Pereira ${ }^{54}$. Como brillantemente ha estudiado Sarah Schroth, un primer grupo de 13 bustos "con sus pedestrales altos" fue emplazado en los nichos de uno de los muros laterales del llamado "Jardín de los emperadores", al que se unía otra serie de 6 nuevas estatuas de emperadores situada también

\footnotetext{
leerse en Di Dio/Coppel, 2013: 65-82.

50 El proyecto fue terminado por Pietro Tacca. Como comentan Di Dio y Coppel, el conjunto llegó a Madrid en 1616 y fue instalado en los jardines de la Casa de Campo, contrariamente a lo esperado por Ferdinando de Médici, quien hubiese querido que se instalase en el Alcázar. Di Dio/Coppel, 2013: 23 y 44. Goldberg, 1996b: 532 y ss.

${ }^{51}$ Chabás, 1876: tomo II, 288-289.

52 Autos del pleito seguido entre el Duque de Medinaceli y los tres fiscales del Supremo Tribunal de Justicia, sobre indemnización de la ciudad de Denia, su término y puerto, incorporados á la Corona por real orden de 8 de enero de 1804, 1804-1857, Toledo (ADM), Denia-Lerma, legajo 21, n. 32, fol. 45r.

53 Di Dio/Coppel, 2013: 11 .

${ }^{54}$ Schroth, 2001b: 12. Desconocemos si se trataban de originales antiguos o de copias renacentistas. Lamentablemente, hoy están desaparecidos. Sobre las colecciones escultóricas del duque de Lerma hasta ahora conocidas véase Schroth, 2001b. Di Dio/Coppel, 2013: 144 y ss. y 176 y ss.
} 
dentro de este mismo espacio. Por último, los 5 restantes emperadores, esta vez "con sus pedestalas baxos", se encontraban alrededor del más grande de los estanques reflectantes de la llamada Huerta de Abajo $^{55}$.

Las esculturas de emperadores romanos en los jardines palaciegos de Lerma no sólo otorgaban a su nueva propiedad madrileña distinción y valor ${ }^{56}$, pues le permitían además adquirir unos conocimientos directos sobre el mundo Antiguo que, efectivamente, ya se habían puesto de manifiesto en sus coetáneos encargos artísticos, como fue por ejemplo la idea de basar el famoso retrato de Rubens en una estatua ecuestre imperial de la escultura antigua y del Renacimiento italiano ${ }^{57}$. Asimismo, sabedor de las implicaciones ideológicas que suponía el exclusivo encargo genovés, Lerma se hizo representar nuevamente a la manera imperial, como alter ego del rey Felipe III y como general victorioso con los atributos de su cargo de General de la Caballería de España ${ }^{58}$.

En este sentido, su retrato esculpido de Dénia puede interpretarse desde un punto de vista más tradicional, es decir, en base a su capacidad para rememorar el ausente y perpetuar su memoria, y como reafirmación de la personalidad de un personaje que ha pasado a los anales como el valido más poderoso de la historia de España. No obstante, el mayor enemigo de un retrato es, claro está, el paso del tiempo, y "contra la amnesia del tiempo y la fragilidad de la memoria" cabe un auxilio, la escritura ${ }^{59}$. A ella recurrieron Luis Ramón de Aragón y Mariana de Sandoval en 1659 cuando ordenaron la inscripción de un letrero en el pedestal de la estatua que certificaba, en efecto, que se estaba ante la efigie del duque de Lerma ${ }^{60}$. Al mismo tiempo, dicha leyenda no hacía sino redundar en la transmisión de los títulos y nobleza de un individuo que de alguna forma ya se hacía visible a través de los atributos y blasones del encargo original. Realmente, aquello que buscaban los duques de Segorbe era proclamar la identidad y méritos del duque de Lerma, con quien emparentaba su hijo Ambrosio de Sandoval, señalando así su relación de parentesco con un linaje que le dignificaba y enorgullecía.

Esta honra específicamente caballeresca de pertenencia a la estirpe de los Sandovales y Rojas por parte de sus miembros permite ampliar los horizontes de interpretación de la estatua más allá del culto a la personalidad, considerando el encargo como una suerte de reafirmación de esta identidad colectiva. De este modo, la presencia del escudo de armas del duque evocaba como "señal" de nobleza el heroico pasado del linaje ${ }^{61}$; ciertamente, de una forma análoga a como actuaban las explícitas representaciones de batallas en el fondo del ya mencionado retrato ecuestre de Rubens ${ }^{62}$. Asimismo, que Lerma fuese considerado la expresión de la autoridad y voluntad del rey, identificándose como su sombra y reflejo, posibilita una ulterior lectura de la escultura; esto es, como representación de un ente colectivo todavía más amplio: la monarquía hispánica. Así, la colocación de la obra en el castillo de Dénia sólo cuatro años después de la expulsión de los moriscos en la contigua zona costera puede hacernos pensar en una especie de relación metonímica por la que Lerma, como caballero cristiano y gran defensor de la fe, era sombra de la autoridad del monarca y reflejo de la voluntad de España también en aquellas tierras litorales ${ }^{63}$.

Con todo, nada queda en Dénia del esplendor de tan magna obra. Sólo un aséptico pedestal colocado por el consistorio en el siglo XX señala el lugar donde originalmente se erigía impo-

55 Schroth, 2001b: 15-16.

56 Schroth, 2001b: 12.

57 Schroth, 2001a: 43.

58 Sobre la creación sin precedentes de la imagen oficial de Lerma como imitación y semejanza del rey, alentada además por la tratadística política y cortesana de su tiempo, véase el fundamental ensayo de Antonio Feros en Feros, 2002: 175-200. Recuérdense en este sentido los retratos de Felipe III de Juan Pantoja de la Cruz del Kunsthistorisches Museum de Viena (1601-2) y del Museo del Prado (1606), iconográficamente muy similares a los referidos del duque de Lerma.

59 Falomir, 2008: 21.

60 Véase la nota 37.

61 Urquízar, 2014: 93-111.

62 Feros, 2002: 195-196.

${ }^{63}$ Sobre Lerma y la expulsión de los moriscos véase Feros, 2002: 354 y ss. 


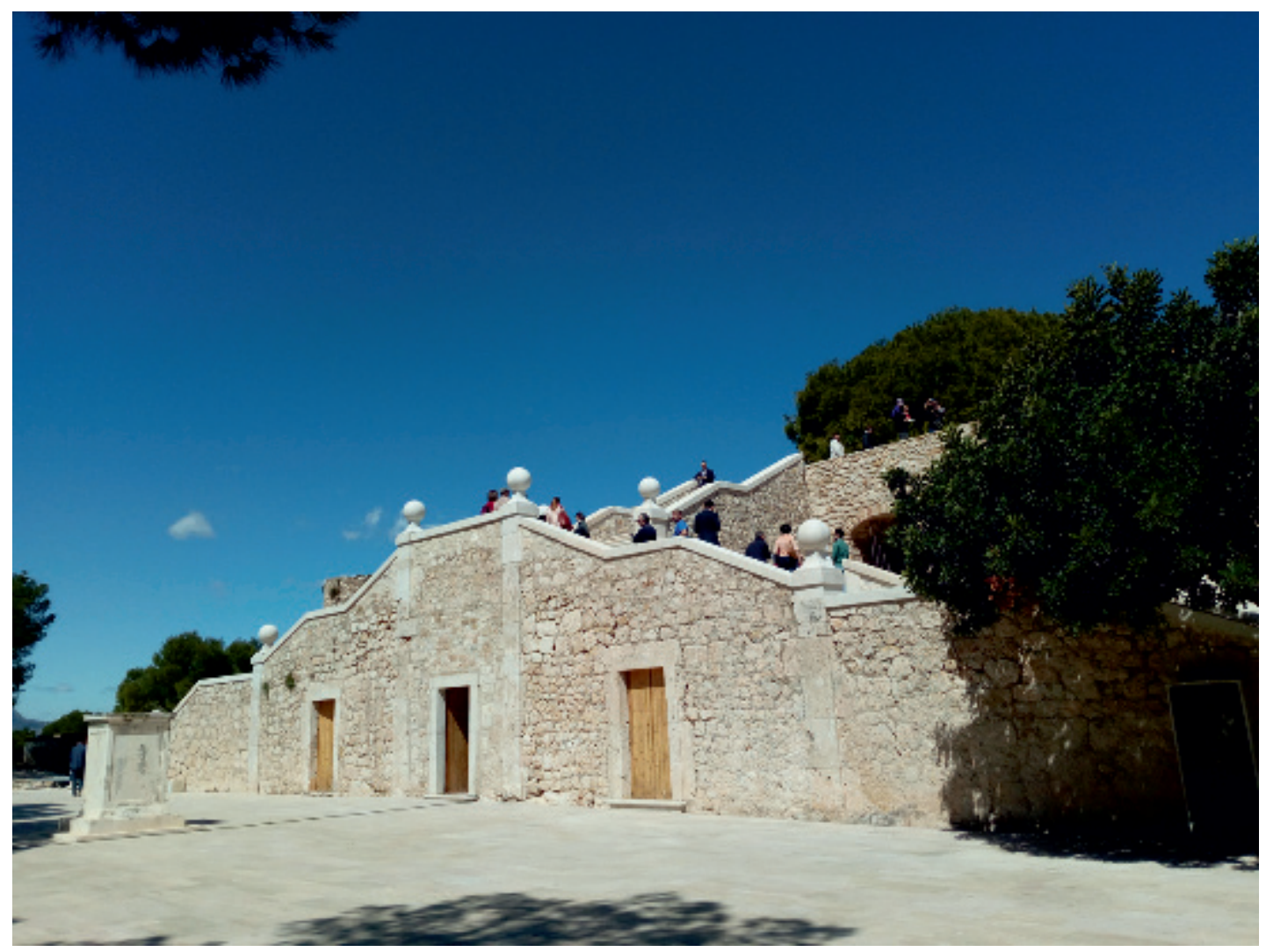

Fig. 10. Estado actual de la plataforma del castillo de Dénia.

nente la figura marmórea del duque de Lerma (fig. 10). De sus casi tres siglos de lustre hemos dado cuenta y razón en estas breves líneas, contemplando no sólo su encargo y llegada a Dénia, sino también la forma en que pudo ser vista y entendida por sus contemporáneos. Sin embargo, la suerte que pudo correr en sus años posteriores es ya otra historia, seguramente igual de apasionante, que deberá ser abordada en futuras investigaciones.

\section{BIBLIOGRAFÍA}

Alfonso, Luigi (1977): "I Carlone a Genova". En: La Berio, 1-2, Génova, pp. 43-98.

Chabás, Roque (1876): Historia de la ciudad de Denia. Dénia: Imprenta de Pedro Botella, II tomos.

Di Dio, Kelley/Coppel, Rosario (2013): Sculpture Collections in Early Modern Spain. Farnham-Burlington: Ashgate.

Falomir, Miguel (2008): “El retrato del Renacimiento. Prólogo a una exposición”. En: Falomir, Miguel (ed.): El retrato del Renacimiento. Madrid: Museo del Prado, pp. 17-22.

Feros, Antonio (2002): El duque de Lerma. Realeza y privanza en la España de Felipe III. Madrid: Marcial Pons.

Franchini, Fausta (2004): "La escultura de los siglos XVII y XVIII. Mármoles y maderas policromadas para la decoración de los palacios y las imágenes de devoción". En: Boccardo, Piero/Colomer, José Luis (eds.): España y Génova. Obras, artistas y coleccionistas. Madrid: Fernando Villaverde Ediciones; Fundación Carolina, pp. 205-221.

Galassi, Maria Clelia (1987): "I Carlone da Rovio". En: La Scultura a Genova e in Liguria. Dal Seicento al Primo Novecento. Genova: Cassa di Risparmio di Genova e Imperia, vol. II, pp. 80-81.

García, Eugenio/Sebastián, Ramón (1983): Análisis histórico del testamento del duque de Lerma, quinto marqués de Dénia. Dénia: Ajuntament de Dénia.

García, Bernardo J. (1998): "Los marqueses de Denia en la Corte de Felipe II. Linaje, servicio y virtud”. En: Martínez, José (dir.): Felipe II (1527-1598): Europa y la monarquía católica. Madrid: Parteluz, pp. 305-331. 
García, Bernardo J. (2004): “Apostillas históricas”. En: Vega, Lope de. Fiestas de Denia. Introducción y texto crítico de M.G. Profeti. Florencia: Alinea, pp. 31-62.

García, Bernardo J. (2016): "Espacios de la privanza. Las residencias del favorito como extensión de los Reales Sitios en tiempos del duque de Lerma (1599-1618)". En: García, Bernardo J. (ed.): Felix Austria. Lazos familiares, cultura política y mecenazgo artístico entre las cortes de los Habsburgo. Madrid: Fundación Carlos de Amberes, pp. 393440.

Goldberg, Edward L. (1996a): "Artistic Relations between the Medici and the Spanish Courts, 1587-1621: Part I". En: The Burlington Magazine, vol. 138, 1115, pp. 105-114.

Goldberg, Edward L. (1996b): “Artistic Relations between the Medici and the Spanish Courts, 1587-1621: Part II”. En: The Burlington Magazine, vol. 138, 1121, pp. 529-540.

Ivars, Josep (2015): Dénia, la ciutat i el castell: l'arquitectura militar baluardada (segles XVI-XIX). Dénia: Ajuntament de Dénia; Valencia: Universitat de València.

Laborde, Alexandre de (1806-1820): Voyage pittoresque et historique de l'Espagne. París: Imprimerié de Pierre Didot, 4 vols.

López Torrijos, Rosa (1978): "Los autores del sepulcro de los marqueses del Zenete". En: Archivo español de arte, tomo 51, 203, pp. 323-336.

López Torrijos, Rosa (1979): "Un palacio genovés en Valencia: el del Embajador Vivas en Benifairó de les Valls". En: Archivo de arte valenciano, 50, pp. 59-69.

López Torrijos, Rosa (1980): “Obras de los Carlone en España”. En: Goya, 158, pp. 80-85.

López Torrijos, Rosa (1987): "La Scultura Genovese in Spagna". En: La Scultura a Genova e in Liguria. Dalle Origini al Cinquecento. Genova: Cassa di Risparmio di Genova e Imperia, vol. I, pp. 366-381.

Montolío, David/Fumanal, Miquel Àngel (2015): "El Palacio Vivas de Cañamás de Benifairó de les Valls". En: Pallantiae documenta, 5, pp. 154-176.

Palau, Marco Antonio (1975): Diana desenterrada. Antiguas memorias y breve recopilación de los más notables sucesos de la ciudad de Denia, desde su antiquísima fundación hasta el estado presente. Edición facsímil del original de 1643. Alicante: Diputación Provincial.

Schroth, Sarah (2001a): "Más allá de la 'identificación del modelo'. Los estudios de Rubens para el retrato ecuestre del duque de Lerma”. En: Schroth, Sarah/Vergara, Alejandro (coms.): Rubens: dibujos para el retrato ecuestre del Duque de Lerma. Madrid: Museo del Prado, cat. exp., pp. 31-46.

Schroth, Sarah (2001b): “The Duke of Lerma's Palace in Madrid. A reconstruction of the original setting for Cristoforo Stati's Samson and the Lion". En: Apollo, 154, pp. 11-21.

Urquízar, Antonio (2014): "Teoría de la magnificencia y teoría de las señales en el pensamiento nobiliario español del siglo XVI". En: Ars Longa, 23, pp. 93-111.

Vega, Lope de (2004): Fiestas de Denia. Introducción y texto crítico de M.G. Profeti; Apostillas históricas de B.J. García; texto original de 1599. Florencia: Alinea.

Venero, Baltasar (2005): Visita senyorial a l'estat de Sogorb (1765) i al marquesat de Dénia (1766). Edición a cargo de Joan Romero y Antoni Grau. Valencia: Universitat de València.

Williams, Patrick (2008): "El favorito del rey: Francisco Gómez de Sandoval y Rojas, V marqués de Denia y I duque de Lerma”. En: Martínez, José/Visceglia, M. a Antonietta (dirs.): La monarquía de Felipe III: La Corte (volumen III). Madrid: Fundación Mapfre-Instituto de Cultura, pp. 185-259.

Williams, Patrick (2010): El gran valido. El duque de Lerma, la corte y el gobierno de Felipe III, 1598-1621. Salamanca: Junta de Castilla y León.

Fecha de recepción: 05-IX-2017

Fecha de aceptación: 15-XII-2017

Archivo Español de Arte, vol. XCI, n. ${ }^{\circ} 364$, pp. 395-410, octubre-diciembre 2018

ISSN: 0004-0428, eISSN: 1988-8511, https://doi.org/10.3989/aearte.2018.24 